Egypt. Acad. J. biolog. Sci., 1(1): 21-31 (2009)

Email: egyptianacademic@yahoo.com

Received: 10/8/2009
C. Physiology \& Molecular Biology

ISSN: 2090-0767

www.eajbs.eg.net

\title{
Physiological effects of envenomation by two different doses of the viper Echis coloratusis crude venom on biochemical parameters in serum of Guinea pigs at different times.
}

\author{
Muhammad M. A. Salman \\ Zoology Department, Faculty of Science, South Valley Univesity, Qena, Egypt.
}

\section{ABSTRACT}

The eastern carpet viper Echis coloratusis widely distributed from Africa (eastern Egypt). In the present study the effects of crude venom of the viper Echis coloratusis on serum biochemical parameters of guinea pigs. Adult male guinea pigs $(550 \pm 25 \mathrm{~g}$ body weigh) were divided into three groups (15 each). In the control group, guinea pigs were interaperitoneally (i.p) injected with $50 \mu \mathrm{L}$ saline solution. The second group was i.p. injected with $0.1 \mu \mathrm{gm} / \mathrm{g}$ b.w. of crude venom in $50 \mu \mathrm{L}$ saline solutions. The third group was i.p. injected with $0.2 \mu \mathrm{gm} / \mathrm{g}$. b.w. of the crude venom in $50 \mu \mathrm{L}$ saline solution. The results indicated that the injection of crude venom of the viper Echis coloratusis induced a significant decrease in total serum protein, albumin, globulin and uric acid within 1,2 and $4 \mathrm{hrs}$. after injection. In contrast, the levels of glucose, cholesterol, triglycerides, urea and creatinine were increased significantly in envenomated Guinea pigs. Viper Echis coloratusis crude venom caused hepatic and renal dysfunction in envenomated Guinea pigs.

Key words: Snake venom, Viper Echis coloratusis, biochemical parameters and Guinea pigs.

\section{INTRODUCTION}

Snake venom is a complex mixture of many substances, such as toxins, enzymes, growth factors, activators, and inhibitors with a wide spectrum of biological activities (Theakston, 1983 and Rahmy and Hemmaid, 2000). They are also known to cause different metabolic disorders by altering the cellular inclusions and enzymatic activities of different organs (Aiesenberg, 1981). The eastern carpet viper Echis coloratusis widely distributed from Africa (eastern Egypt). (Gasperetti, 1988; Cherlin, 1990 and Warrell, 1995). This species has got the highest incidence of snake bites, next to cerastes gasperettii (Al-Sadoon, 1991 and Al-Sadoon et al., 1991). The bites of the Echis genus could be response for the highest mortality level that exceeded all other snake genera, with a death rate of 7-15\% of untreated victims (Moav et al., 1963 and Warrell and Arnett, 1976). Clinical symptoms of Eachis envenomation are characterized by highly complex pathophysiological features of local as well as systemic nature (Warrell, 1993). Several investigators have studied the biochemical and pharmacological effects of the venom from different species that belong genus Echis (Theakston, 1983; Al-Gammaz, et al., 1999 and Yamazaki and Morita, 2007). However, venom components may be altered by the geographical location and habitat of the snake (Zingali et al., 1993; Sasa, 1999 and Salazar et al., 2007). Additionally, zoological distribution and environmental condition could influence the overall biological behavior of snake venoms of the same species (Hassan et al., 1980; Werner et al., 1991; Werner, 1994; Tan and Ponnudurai, 1999; and Warrell, 1997). The present study was designed to investigate the effects of different doses of the viper 
Echis coloratusis crude venom on the serum biochemical parameters of Guinea pigs over a period of time after venom injection.

\section{MATERIALS AND METHODS}

Crude venom was obtained from the eastern carpet viper Echis coloratusis kept in a serpentarium at the Department of Zoology, Faculty of Science, and South Valley University. The snakes were collected from the Qena region of Egypt. Venom was milked, lyophilized, stored in a desiccator at $4{ }^{\circ} \mathrm{C}$ in the dark and reconstituted in saline solution prior to use. $\mathrm{LD}_{50}$ of crude venom was determined as described by Meier and Theakston (1986). The LD 50 of venom was found to be $0.3 \mu \mathrm{gm} / \mathrm{gm}$.of Guinea pigs.

\section{Study design:}

Forty five adult male Guinea pigs weighing 550- $570 \mathrm{~g}$ were used. Guinea pigs were selected from the Animal House Facility of Egyptian Organization for biological products and Vaccines (VACSERA), Helwan, Cairo, Egypt. Animals were housed in standard condition and fed with normal diet and water ad libitum. The Guinea pigs were divided into three groups as the following:

Group I: 15 animals were injected interaperitoneally (i.p.) with $50 \mu \mathrm{L}$ physiological saline $(0.9 \% \mathrm{Na} \mathrm{Cl})$ and served as a control.

Group II: 15 animals were received a single low dose $(0.1 \mu \mathrm{gm} / \mathrm{g}$ body weight $)$ of the viper Echis coloratusis crude venom in $50 \mu \mathrm{L}$ saline solution interaperitoneally (i.p).

Group III: 15 animals were received a single low dose $(0.2 \mu \mathrm{gm} / \mathrm{g}$ body weight $)$ of the viper Echis coloratusis crude venom in $50 \mu \mathrm{L}$ saline solutions interaperitoneally (i.p).

Five animals of each group (I, II and III) were sacrificed at 1, 2 and 4 hours respectively post-injection of crude venom

\section{Serum analysis:}

Blood was collected from each animal into plain centrifuge tubes, left for $1 \mathrm{hr}$. at room temperature for clotting. Serum was separated by centrifugation at $3000 \mathrm{~g}$ for 30 min. and analyzed, for the concentration of total protein, albumin, urea, creatinine, uric acid, glucose, cholesterol and triglycerides determination. Kits purchased from Spinreact, S. A. Ctra. Santa Coloma, Spain. All other chemicals used were of analytical reagent grade. Glucose determination was carried out according to the method Trinder (1969). Determination of total serum protein was estimated according to Peters (1968) method. Serum albumin was determined according to the method described by Doumas et al. (1971 and 1972). While; serum globulin was obtained from the difference between the total serum protein and serum albumin. Cholesterol was determined by enzymatic method as described by Richmond (1973), while triglycerides were determined by the enzymatic colorimetric method as described by Young (1975). Creatinine was determined by kinetic method described by Hare (1950), while determination of urea was according to the enzymatic method of (Patton and Crouch, 1977). Serum uric acid was determined by quantitative determination method of Young (1975).

\section{Statistical analysis:}

Data are presented as standard error (S.E.) of the means and were statistically analyzed using SPSS version 8.0 for Software. Differences between moments were analyzed by Kruskal-Wallis Test and parameters of each test group were compared with control group by Mann-Whitney Test. Results were considered significant when $\mathrm{p}$ value was lower than 0.05 . 


\section{RESULTS}

1- Effects of the different doses (i.p) injection of viper Echis coloratusis crude venom on the levels of serum total proteins, albumin and globulin in serum.

A) Serum total protein content: The results presented in table (1) show that the i.p. injection of $0.1 \mu \mathrm{gm} / \mathrm{gm}(\mathrm{b} . \mathrm{w}$.) in the serum of Guinea pigs did not induce significant difference change of their serum total protein content from their corresponding control values after 1 hour. On the other hand, i.p. injection of $0.1 \mu \mathrm{gm} / \mathrm{gm}$ induced significant decreases of their means of serum total protein content. These decreases were pronouncing and reached 19.82\% $(\mathrm{P}<0.05)$ after 2 hours and $26.54 \%(\mathrm{P}<0.01)$ after 4 hours. However, the injection of $0.2 \mu \mathrm{gm} / \mathrm{gm}$ (b. w.) of the crude venom after 1,2 and 4 hours of injection caused significant decreases of the means serum total protein levels from that of the corresponding control value. These decreases were pronouncing and reached $20.63 \%(\mathrm{P}<0.05)$ after1 hour, 29.95\% $(\mathrm{P}<0.01)$ after 2 hours and $37.09 \%(\mathrm{P}<0.01)$ after 4 hours (Table 1$)$.

Table (1): The Effects of the different doses( i.p) injection of viper Echis coloratusis crude venom on the levels of serum total proteins $(\mathrm{mg} / \mathrm{dl})$, albumin $(\mathrm{mg} / \mathrm{dl})$ and globulin $(\mathrm{mg} / \mathrm{dl})$ in Guinea pigs at the 1,2 and 4 hours after crude venom injection.

\begin{tabular}{|c|c|c|c|c|c|}
\hline \multirow[b]{2}{*}{ Time } & \multirow{2}{*}{\multicolumn{2}{|c|}{ Parameter }} & \multicolumn{3}{|c|}{ Experimental and doses } \\
\hline & & & $\begin{array}{c}\text { Group1 } \\
(0.9 \mathrm{NaCl})\end{array}$ & $\begin{array}{c}\text { Group 2 } \\
(0.1 \mu \mathrm{gm} / \mathrm{g} .)\end{array}$ & $\begin{array}{c}\text { Group2 } \\
(0.2 \mu \mathrm{gm} / \mathrm{g})\end{array}$ \\
\hline \multirow{3}{*}{ 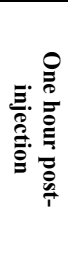 } & Total protein & $\begin{array}{c}\text { Mean } \pm \text { S.E } \\
\text { Change \% } \\
P \text { - value }\end{array}$ & $6.30 \pm 0.34$ & $\begin{array}{c}6.10 \pm 0.39 \\
-3.17 \% \\
\text { N.S. }\end{array}$ & $\begin{array}{c}5.00 \pm 0.30 \\
-20.63 \% \\
P<0.05\end{array}$ \\
\hline & Albumin & $\begin{array}{c}\text { Mean } \pm \text { S.E } \\
\text { Change \% } \\
\mathrm{P}-\text { value }\end{array}$ & $3.31 \pm 0.21$ & $\begin{array}{c}3.22 \pm 0.13 \\
-2.72 \% \\
\text { N.S. }\end{array}$ & $\begin{array}{c}2.97 \pm 0.23 \\
-10.27 \% \\
\mathrm{P}<0.05\end{array}$ \\
\hline & Globulin & $\begin{array}{c}\text { Mean } \pm \text { S.E } \\
\text { Change \% } \\
P \text { - value }\end{array}$ & $3.01 \pm 0.32$ & $\begin{array}{c}2.89 \pm 0.24 \\
-3.99 \% \\
\text { N.S. }\end{array}$ & $\begin{array}{c}2.03 \pm 0.11 \\
-32.56 \% \\
P<0.01\end{array}$ \\
\hline \multirow{3}{*}{ 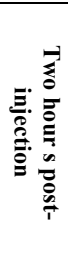 } & Total protein & $\begin{array}{c}\text { Mean } \pm \text { S.E } \\
\text { Change \% } \\
P-\text { value }\end{array}$ & $6.51 \pm 0.11$ & $\begin{array}{c}5.22 \pm 0.21 \\
-19.82 \% \\
\mathrm{P}<0.05\end{array}$ & $\begin{array}{c}4.56 \pm 0.26 \\
-29.95 \% \\
P<0.01\end{array}$ \\
\hline & Albumin & $\begin{array}{c}\text { Mean } \pm \text { S.E } \\
\text { Change \% } \\
P-\text { value }\end{array}$ & $3.54 \pm 0.31$ & $\begin{array}{c}3.22 \pm 0.12 \\
-9.04 \% \\
\text { NS }\end{array}$ & $\begin{array}{c}2.77 \pm 0.15 \\
-21.75 \% \\
P<0.05\end{array}$ \\
\hline & Globulin & $\begin{array}{c}\text { Mean } \pm \text { S.E } \\
\text { Change \% } \\
\mathrm{P}-\text { value }\end{array}$ & $2.97 \pm 0.22$ & $\begin{array}{c}2.0 \pm 0.13 \\
-32.66 \% \\
\mathrm{P}<0.01\end{array}$ & $\begin{array}{c}1.79 \pm 0.25 \\
-39.73 \% \\
P<0.01\end{array}$ \\
\hline \multirow{3}{*}{ 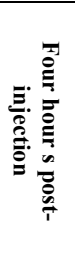 } & Total protein & $\begin{array}{c}\text { Mean } \pm \text { S.E } \\
\text { Change \% } \\
\mathrm{P}-\text { value }\end{array}$ & $6.39 \pm 0.44$ & $\begin{array}{c}4.70 \pm 0.12 \\
-26.45 \% \\
\mathrm{P}<0.01\end{array}$ & $\begin{array}{c}4.02 \pm 0.29 \\
-37.09 \% \\
P<0.01\end{array}$ \\
\hline & Albumin & $\begin{array}{c}\text { Mean } \pm \text { S.E } \\
\text { Change \% } \\
\mathrm{P}-\text { value }\end{array}$ & $3.44 \pm 0.37$ & $\begin{array}{c}2.82 \pm 0.13 \\
-18.02 \% \\
\mathrm{P}<0.05\end{array}$ & $\begin{array}{c}2.33 \pm 0.19 \\
-32.27 \% \\
P<0.01\end{array}$ \\
\hline & Globulin & $\begin{array}{c}\text { Mean } \pm \text { S.E } \\
\text { Change \% } \\
\mathrm{P}-\text { value }\end{array}$ & $2.95 \pm 0.39$ & $\begin{array}{c}1.88 \pm 0.32 \\
-36.27 \% \\
\mathrm{P}<0.01\end{array}$ & $\begin{array}{c}1.69 \pm 0.25 \\
-42.71 \% \\
P<0.01\end{array}$ \\
\hline
\end{tabular}

$\mathrm{N}=5$ animals were used in each group.

$\mathrm{P}=$ Significantly different from the control.

NS =Insignificant different from the control.

B) Serum albumin content: Table (1) show also that the i.p. injection of $0.1 \mu \mathrm{gm} / \mathrm{gm}$ (b. w.) in the Guinea pigs did not induce significant difference change of their serum albumin content from their corresponding control values after 1 and 2 hour. However, i.p. injection of $0.1 \mu \mathrm{gm} / \mathrm{gm}$ induced significant decreases of the mean of serum albumin content. These decrease was pronouncing and reached $18.02 \%(\mathrm{P}<0.05)$ after 4 hours. On the other hand, the injection of $0.2 \mu \mathrm{gm} / \mathrm{gm}$ (b. w.) of the crude venom after 1, 2 and 4 hours of injection caused significant decreases of the means serum albumin levels from that of the corresponding control value. These decreases 
were pronouncing and reached 10.27\% $(\mathrm{P}<0.05), 21.75 \%(\mathrm{P}<0.05)$ and $32.27 \%$ $(\mathrm{P}<0.01)$ after 1, 2 and 4 hours of injection, respectively as shown (Table 1).

C) Serum globulin content: As indicated in table (1) also that the i.p. injection of $0.1 \mu \mathrm{gm} / \mathrm{gm}$ did not induce significant difference change of their serum globulin content from their corresponding control values after 1 hour. However, i.p. injection of $0.2 \mu \mathrm{gm} / \mathrm{gm}$ induced significant decreases of the means of serum globulin content. These decreases were pronouncing and reached 32.66\% $(\mathrm{P}<0.01)$ and $36.27 \%$ $(\mathrm{P}<0.01)$ after 2 and 4 hours, respectively. On the other hand, the injection of $0.2 \mu \mathrm{gm} / \mathrm{gm}$ (b. w.) of the crude venom after 1,2 and 4 hours of injection caused significant decreases of the means serum globulin levels from that of the corresponding control value. These decreases were pronouncing and reached $32.56 \%$ $(\mathrm{P}<0.01), 39.73 \%(\mathrm{P}<0.01)$ and $42.71 \%(\mathrm{P}<0.01)$ after 1,2 and 4 hours of injection, respectively as shown (Table 1$)$.

2- Effects of the different doses ( i.p) injection of viper Echis coloratusis crude venom on the levels of creatinine, urea and uric acid.

A) Serum creatinine content: The results presented in table (2) show that the injection of $0.1 \mu \mathrm{gm} / \mathrm{gm}$ to Guinea pigs caused significant increases in serum creatinine. These increases were $33.33 \%(\mathrm{P}<0.05), 95.56 \%(\mathrm{P}<0.01)$ and $95.65 \%(\mathrm{P}<0.01)$ after 1,2 and 4 hours of injection, respectively. On the other hand, the injection of crude venom; $0.2 \mu \mathrm{gm} / \mathrm{gm}$ caused also significant increases. These increases were $102.38 \%$ $(\mathrm{P}<0.001), 211.11 \%(\mathrm{P}<0.001)$ and $182.61 \%(\mathrm{P}<0.001)$ after 1,2 and 4 hours of injection, respectively as shown in (Table 2$)$.

Table (2): The Effects of the different doses ( i.p) injection of viper Echis coloratusis crude venom on the levels of serum creatinine $(\mathrm{mg} / \mathrm{dl})$, urea $(\mathrm{mg} / \mathrm{dl})$ and uric acid $(\mathrm{mg} / \mathrm{dl})$ in Guinea pigs at the 1,2 and 4 hours after crude venom injection.

\begin{tabular}{|c|c|c|c|c|c|}
\hline \multirow[b]{2}{*}{ Time } & \multirow{2}{*}{\multicolumn{2}{|c|}{ Parameter }} & \multicolumn{3}{|c|}{ Experimental and doses } \\
\hline & & & $\begin{array}{c}\text { Group1 } \\
(0.9 \mathrm{NaCl})\end{array}$ & $\begin{array}{c}\text { Group 2 } \\
(0.1 \mu \mathrm{gm} / \mathrm{g} .)\end{array}$ & $\begin{array}{c}\text { Group2 } \\
(0.2 \mu \mathrm{gm} / \mathrm{g})\end{array}$ \\
\hline \multirow{3}{*}{ 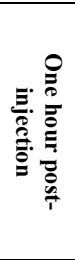 } & Creatinine & $\begin{array}{c}\text { Mean } \pm \text { S.E } \\
\text { Change \% } \\
\text { P-value }\end{array}$ & $0.42 \pm .06$ & $\begin{array}{c}0.56 \pm 0.03 \\
+33.33 \% \\
\mathrm{P}<0.05\end{array}$ & $\begin{array}{c}0.85 \pm 0.04 \\
+102.38 \% \\
\mathrm{P}<0.001\end{array}$ \\
\hline & Urea & $\begin{array}{c}\text { Mean } \pm \text { S.E } \\
\text { Change \% } \\
\text { P-value }\end{array}$ & $36.33 \pm 3.6$ & $\begin{array}{c}55.44 \pm 2.70 \\
+52.60 \% \\
\mathrm{P}<0.01 \\
\end{array}$ & $\begin{array}{c}66.77 \pm 3.40 \\
+83.79 \% \\
\mathrm{P}<0.01 \\
\end{array}$ \\
\hline & Uric acid & $\begin{array}{c}\text { Mean } \pm \text { S.E } \\
\text { Change \% } \\
\text { P - value }\end{array}$ & $1.5 \pm 0.04$ & $\begin{array}{c}1.4 \pm 0.08 \\
-6.67 \% \\
\text { NS }\end{array}$ & $\begin{array}{c}1.2 \pm 0.04 \\
-20 \% \\
\mathrm{P}<0.05\end{array}$ \\
\hline \multirow{3}{*}{ 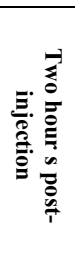 } & Creatinine & $\begin{array}{c}\text { Mean } \pm \text { S.E } \\
\text { Change \% } \\
\text { P-value }\end{array}$ & $0.45 \pm 0.07$ & $\begin{array}{c}0.88 \pm 0.04 \\
+95.56 \% \\
\mathrm{P}<0.01\end{array}$ & $\begin{array}{c}1.4 \pm 0.09 \\
+211.11 \% \\
\mathrm{P}<0.001\end{array}$ \\
\hline & Urea & $\begin{array}{c}\text { Mean } \pm \text { S.E } \\
\text { Change \% } \\
\text { P-value }\end{array}$ & $42.22 \pm 3.20$ & $\begin{array}{c}90.44 \pm 3.30 \\
+114.21 \% \\
\mathrm{P}<0.01\end{array}$ & $\begin{array}{c}99.98 \pm 3.60 \\
+136.81 \% \\
\mathrm{P}<0.001 \\
\end{array}$ \\
\hline & Uric acid & $\begin{array}{c}\text { Mean } \pm \text { S.E } \\
\text { Change \% } \\
\text { P-value }\end{array}$ & $1.6 \pm 0.06$ & $\begin{array}{c}1.2 \pm 0.06 \\
-25.00 \% \\
\mathrm{P}<0.05\end{array}$ & $\begin{array}{c}0.90 \pm 0.05 \\
-43.75 \% \\
\mathrm{P}<0.05\end{array}$ \\
\hline \multirow{3}{*}{ 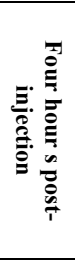 } & Creatinine & $\begin{array}{c}\text { Mean } \pm \text { S.E } \\
\text { Change \% } \\
\text { P-value }\end{array}$ & $0.46 \pm 0.07$ & $\begin{array}{c}0.90 \pm 0.04 \\
+95.65 \% \\
\mathrm{P}<0.01 \\
\end{array}$ & $\begin{array}{c}1.3 \pm 0.08 \\
+182.61 \% \\
\mathrm{P}<0.001\end{array}$ \\
\hline & Urea & $\begin{array}{c}\text { Mean } \pm \text { S.E } \\
\text { Change \% } \\
\text { P-value }\end{array}$ & $42.22 \pm 3.30$ & $\begin{array}{c}87.44 \pm 2.50 \\
+107.11 \% \\
\mathrm{P}<0.01\end{array}$ & $\begin{array}{c}98.99 \pm 2.40 \\
+134.46 \% \\
\mathrm{P}<0.01\end{array}$ \\
\hline & Uric acid & $\begin{array}{c}\text { Mean } \pm \text { S.E } \\
\text { Change \% } \\
\mathrm{P}-\text { value }\end{array}$ & $1.50 \pm 0.08$ & $\begin{array}{c}1.10 \pm 0.09 \\
-26.67 \% \\
P<0.05 \\
\end{array}$ & $\begin{array}{c}0.88 \pm 0.05 \\
-41.33 \% \\
\mathrm{P}<0.05 \\
\end{array}$ \\
\hline
\end{tabular}

$\mathrm{N}=5$ animals were used in each group.

$\mathrm{P}=$ significantly different from the control.

$\mathrm{NS}=$ Insignificant

B) Serum urea content: The results presented in table (2) show that the injection of $0.1 \mu \mathrm{gm} / \mathrm{gm}$ to Guinea pigs caused significant increases in serum urea. These increases were $52.60 \%(\mathrm{P}<0.01), 114.21 \%(\mathrm{P}<0.01)$ and $107.11 \%(\mathrm{P}<0.01)$ after 1,2 and 4 hours of injection crude venom, respectively. The injection of crude venom; 
$0.2 \mu \mathrm{gm} / \mathrm{gm}$ caused also significant increases. These increases were $83.79 \%(\mathrm{P}<0.01)$, $136.81 \%(\mathrm{P}<0.001)$ and $134.46 \%(\mathrm{P}<0.01)$ after 1,2 and 4 hours of injection, respectively as shown in (Table 2 ).

C) Serum uric acid content: As indicated in table (2), the present study shows that the injection of $0.1 \mu \mathrm{gm} / \mathrm{gm}$ to Guinea pigs caused non significant decrease in serum uric acid 1 hour of injection. However, after 2 and 4 hours of injection of $0.1 \mu \mathrm{gm} / \mathrm{gm}$ the decreases were significantly. On the other hand, the injection of $0.2 \mu \mathrm{gm} / \mathrm{gm}$ to Guinea pigs caused significant decreases in serum uric. These decreases were $(20 \%$; $\mathrm{P}<0.05,43.75 \% ; \mathrm{P}<0.05$ and $41.33 \% ; \mathrm{P}<0.05)$ after 1,2 and 4 hours, respectively.

3- Effects of the different doses (i.p) injection of viper Echis coloratusis crude venom on the levels of creatinine, urea and uric acid.

A) The levels of serum glucose: The presented in table (3) show that the injection of $0.1 \mu \mathrm{gm} / \mathrm{gm}$ to animals caused significant increases in serum glucose. These increases were $(56.88 \% ; \mathrm{P}<0.05,55.78 \% ; \mathrm{P}<0.05$ and $49.39 \% ; \mathrm{P}<0.05)$ after 1,2 and 4 hours of injection, respectively. The injection of crude venom; $0.2 \mu \mathrm{gm} / \mathrm{gm}$ caused also significant increases. These increases were $83.99 \%(\mathrm{P}<0.05), 74.21 \%(\mathrm{P}<0.05)$ and $54.54 \%(\mathrm{P}<0.05)$ after 1,2 and 4 hours of injection, respectively as shown in (Table 3$)$.

Table (3): The Effects of the different doses ( i.p) injection of viper Echis coloratusis crude venom on the levels of serum glucose $(\mathrm{mg} / \mathrm{dl})$, cholesterol $(\mathrm{mg} / \mathrm{dl})$ and triglycerides $(\mathrm{mg} / \mathrm{dl})$ in Guinea pigs at the 1,2 and 4 hours after crude venom injection.

\begin{tabular}{|c|c|c|c|c|c|}
\hline \multirow[b]{2}{*}{ Time } & \multirow{2}{*}{\multicolumn{2}{|c|}{ Parameter }} & \multicolumn{3}{|c|}{ Experimental and doses } \\
\hline & & & Group1 & Group 2 & Group2 \\
\hline \multirow{3}{*}{ 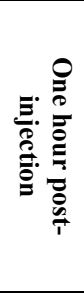 } & Glucose & $\begin{array}{c}\text { Mean } \pm \text { S.E } \\
\text { Change } \% \\
\mathrm{P}-\text { value }\end{array}$ & $99.7 \pm 6.22$ & $\begin{array}{c}156.41 \pm 6.32 \\
+56.88 \% \\
\mathrm{P}<0.05\end{array}$ & $\begin{array}{c}183.44 \pm 5.22 \\
83.99 \%+ \\
\mathrm{P}<0.05\end{array}$ \\
\hline & Cholesterol & $\begin{array}{c}\text { Mean } \pm \text { S.E } \\
\text { Change \% } \\
\mathrm{P} \text { - value }\end{array}$ & $85.5 \pm 7.41$ & $\begin{array}{c}140.33 \pm 7.11 \\
+64.13 \% \\
\mathrm{P}<0.05\end{array}$ & $\begin{array}{c}155.32 \pm 3.33 \\
+81.66 \% \\
\mathrm{P}<0.05\end{array}$ \\
\hline & Triglycerides & $\begin{array}{c}\text { Mean } \pm \text { S.E } \\
\text { Change } \% \\
\mathrm{P}-\text { value }\end{array}$ & $84.11 \pm 5.22$ & $\begin{array}{c}123.55 \pm 5.11 \\
+46.89 \% \mathrm{P}<0.05\end{array}$ & $\begin{array}{c}142.22 \pm 3.11 \\
+69.09 \% \\
\mathrm{P}<0.05 \\
\end{array}$ \\
\hline \multirow{3}{*}{  } & Glucose & $\begin{array}{c}\text { Mean } \pm \text { S.E } \\
\text { Change \% } \\
\mathrm{P} \text { - value }\end{array}$ & $97.71 \pm 5.11$ & $\begin{array}{c}152.21 \pm 3.22 \\
+55.78 \% \\
\mathrm{P}<0.05\end{array}$ & $\begin{array}{c}170.22 \pm 5.22 \\
+74.21 \% \\
\mathrm{P}<0.05\end{array}$ \\
\hline & Cholesterol & $\begin{array}{c}\text { Mean } \pm \text { S.E } \\
\text { Change } \% \\
\mathrm{P} \text { - value }\end{array}$ & $85.77 \pm 7.42$ & $\begin{array}{c}130.44 \pm 6.44 \\
+52.08 \% \\
\mathrm{P}<0.05\end{array}$ & $\begin{array}{c}150.00 \pm 3.44 \\
+74.89 \% \\
\mathrm{P}<0.05\end{array}$ \\
\hline & Triglycerides & $\begin{array}{c}\text { Mean } \pm \text { S.E } \\
\text { Change } \% \\
\mathrm{P}-\text { value }\end{array}$ & $80.33 \pm 4.44$ & $\begin{array}{c}105.50 \pm 5.21 \\
+31.33 \% \\
\mathrm{P}<0.05\end{array}$ & $\begin{array}{c}130.00 \pm 3.43 \\
+61.83 \% \\
\mathrm{P}<0.05\end{array}$ \\
\hline \multirow{3}{*}{ 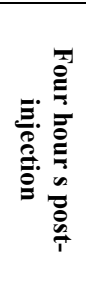 } & Glucose & $\begin{array}{c}\text { Mean } \pm \text { S.E } \\
\text { Change } \% \\
\mathrm{P} \text { - value }\end{array}$ & $97.23 \pm 5.35$ & $\begin{array}{c}145.25 \pm 4.11 \\
+49.39 \% \\
\mathrm{P}<0.05 \\
\end{array}$ & $\begin{array}{c}150.26 \pm 7.33 \\
+54.54 \% \\
\mathrm{P}<0.05 \\
\end{array}$ \\
\hline & Cholesterol & $\begin{array}{c}\text { Mean } \pm \text { S.E } \\
\text { Change } \% \\
\mathrm{P} \text { - value }\end{array}$ & $87.55 \pm 7.44$ & $\begin{array}{c}120.33 \pm 3.11 \\
+37.44 \% \\
\mathrm{P}<0.05 \\
\end{array}$ & $\begin{array}{c}137.11 \pm 5.24 \\
+56.61 \% \\
\mathrm{P}<0.05 \\
\end{array}$ \\
\hline & Triglycerides & $\begin{array}{c}\text { Mean } \pm \text { S.E } \\
\text { Change \% } \\
\mathrm{P} \text { - value }\end{array}$ & $81.44 \pm 6.22$ & $\begin{array}{c}102.00 \pm 4.11 \\
+25.25 \% \\
\mathrm{P}<0.05\end{array}$ & $\begin{array}{c}120.33 \pm 6.25 \\
+47.75 \% \\
\mathrm{P}<0.05\end{array}$ \\
\hline
\end{tabular}

B) The levels of serum cholesterol: The results presented in table (3) show that the injection of $0.1 \mu \mathrm{gm} / \mathrm{gm}$ to animals caused significant increases in serum cholesterol. These increases were 64.13\% $(\mathrm{P}<0.05), 52.08 \%(\mathrm{P}<0.05)$ and $37.44 \%(\mathrm{P}<0.05)$ after 1,2 and 4 hours of injection crude venom, respectively. The injection of crude venom; $0.2 \mu \mathrm{gm} / \mathrm{gm}$ caused also significant increases. These increases were $81.66 \%(\mathrm{P}<0.05)$, $74.89 \%(\mathrm{P}<0.05)$ and $56.61 \%(\mathrm{P}<0.05)$ after 1,2 and 4 hours of injection, respectively as shown in (Table 3 ). 
C) The levels of serum triglycerides: As indicated in table (3), the present study shows that the injection of $0.1 \mu \mathrm{gm} / \mathrm{gm}$ to Guinea pigs caused significant increases in serum triglycerides. These increases were $46.89 \%(\mathrm{P}<0.05), 31.33 \%(\mathrm{P}<0.05)$ and $25.25 \%(\mathrm{P}<0.05)$ after 1,2 and 4 hours of injection crude venom, respectively. The injection of crude venom; $0.2 \mu \mathrm{gm} / \mathrm{gm}$ caused also significant increases. These increases were $(69.09 \% ; \mathrm{P}<0.05,61.83 \% ; \mathrm{P}<0.05$ and $47.75 \%$; $\mathrm{P}<0.05)$, after 1,2 and 4 hours of injection, respectively as shown in (Table 3 ).

\section{DISCUSSION}

Several works dealing with the effects of snake venoms in blood cells, marrow cells and in cells from other organs of animals, like muscle, liver, kidney and skin, showed varying results, depending on the experimental concentrations, exposure time, site of injection, and type of toxin (Maria et al., 2003 and Fox and Serrano, 2008). The liver is a major producer for most of serum proteins and its total level in the blood is a main liver function test. It is established that liver is the main source of plasma albumin. Decrease in plasma albumin is mainly due to the diminishing of its synthesis in hepatic cells, accompanied by losses of large amounts of albumin into the urine and gastrointestinal tract due to damage kidney and intestinal mucosa (West, 1985). It is worth mentioning that bone marrow is the main site of immunoglobulin production. Bone marrow plasma cells are derived from plasma plastic cells that have been generated in the peripheral lymphoid organs following antigen stimulation and have migrated to the bone marrow. These cells find in the bone marrow environment the survival and activation signals that allow them to generate mature plasma cells to produce high amounts of Igs (Hibi and Dosh, 1986; Liu et al., 1992 and MacMillan et al., 1994). Moreover, cytokines such as IL-6 and IL-10 control the production of Igs by non-dividing mature plasma cells (Roldan et al., $1992 \mathrm{a}$ and b).

The present study revealed (Table 1) that, the injection of crude venom of viper Echis coloratusis causes a reduction in serum total proteins, albumin, globulin and uric acid in envenomated Guinea pigs at 1,2 and 4 hours post-injection of crude venom. These findings are in agreement with other investigators who reported that, the reduction in serum total proteins, albumin, globulin and uric acid in envenomated rats was observed in laboratory animals injected with viper snake venoms (AbdulNabi et al., 1997; Fahim 1998 and Al-Jammaz et al., 1998 and 1999). It might be assumed that, the reduced levels of these serum constituents could be due to disturbances in renal functions as well as haemorrhages in some internal organs. In addtion, the increasing in vascular permeability and haemorrhages in vital organs due to the toxic action of various snake venoms were described by (Meier and Stocker 1991; March et al., 1997).

High levels creatinine indicates several disturbances in the kidney (Maxine and Benjamine, 1985). In the present study (Table 2), the rise in serum urea and creatinine levels indicates impairment of renal function. Similar observations were reported in rats following administration of various viper venoms (Abdel-Nabi, 1993; Rahmy et al., 1995; Omran et al., 1997; Abdel-Nabi et al., 1997 and Schneemann et al., 2004). Such increased vascular permeability, together with, renal damage would further aggravate the accompanying hypoproteinemia and hypoalbuminaemia. Furthermore, the rise in serum urea and creatinine associated with the reduction of serum uric acid level observed, in the present study, supports the proposed impairment of renal function. Similar observations were reported following various viper envenomation of rats (Sant and Purandare, 1972; Rahmy et al., 1995; Abdul- 
Nabi et al., 1997 and Omran et al., 1997). The findings that urea and creatinine acutely increased after the Bothrops jararaca venom infusion confirmed the acute renal damage in the present study experimental model and are in agreement with previous studies (Burdmann et al., 1993) in which a significant decrease in the glomerular filtration rate and diuresis were observed in anesthetized rats infused with the crude venom of snake Bothrops jararaca.

The increases in serum cholesterol and triglycerides levels in envenomated Guinea pigs observed in the present study (Table 3), could be due to the hepatocytes damage rendering them unable to phosphorylate the increasing amounts of fatty acids, hence leading to fatty liver and alteration of cell membranes of tissues (El-Asmar et al., 1979). Such disturbances of serum electrolytes were reported in rats following various snake venom injections (Mohamed et al., 1964; Al-Jammaz, 1995 and Lewis and Gutmann, 2004). Furthermore, Meier and Stocker (1991) suggested that, these disturbances might be due to acute nephropathy following viper bites. In addition, Mohamed et al (1980) speculate that this effect was brought about by stimulation of adrenal cortex leading to aldosterone secretion. It worthy to mention that, several studies have been made on the metabolic, cardiovascular and haematological effects of viper venoms on man and experimental animals (Tilbury et al., 1987; Soslau et al., 1988; Abu-Sinna et al., 1993; Abdul-Nabi et al., 1997 and Fahim, 1998), and found that, various venoms viper cause alterations of rat metabolism (Al-Jammaz et al., 1998 and 1999). Furthermore, several workers reported that, acute renal failure characterized by vascular lesions and tubular necrosis in the renal cortex following various snake bites (Tilbury et al., 1987).

It is well known that, snakes venoms caused an increase in serum glucose level in the envenomated animals. Snake venoms were found to produce hyperglyceamia in rats and mice (Mohamed et al., 1980; Abdul-Nabi et al., 1997; Fahim, 1998 and AlJammaz et al., 1999; Pung et al., 2005 and Sleat et al., 2006).

In the present study, the levels of serum glucose were significantly increased after 1, 2 and 4 hours in the envenomated guinea pigs. The increases in serum glucose levels could be attributed to the effects of the venom on glycogen metabolism in the hepatocytes, muscle fibers and medullary catecholamines that stimulate glycogenolysis and gluconeogenesis in those tissues (Ohhira et al., 1991, Abdul-Nabi et al., 1997 and March et al., 1997).

In conclusion, the measurements of biochemical parameters following viper Echis coloratusis crude venom injection, clearly demonstrate the disturbances of vital organs, especially liver, kidney, bone marrow and muscles. Such these disturbances are remaining for $4 \mathrm{hr}$ after envenomation of Guinea pigs at least.

\section{REFERENCES}

Abdul-Nabi, I. M. (1993):Effect of crude Cerastes cerastes venom and fraction B clinical biochemical parameters of white rat .J. Egypt Ger. S. Zool.,10(A): 315-326.

Abdul-Nabi, I. M.; Raafat, A. and El-Shamy, H. I. (1997): Biological effects of intraperitoneal injection of rats with the venom of the snake Echis carinatus, Egypt. J. Zool., 29: 195-205.

Abu-Sinna, G.; AL-Zahaby, A. S.; Abd EL-Aal, A.; Abd-EL-Baset, A. and Soliman, N. A. (1993): The Effect of the viper Cerastes cerastes cerastes venom and venom fractions on carbohydrate metabolism. Toxicon, 31(6): 791- 801. 
Aiesenberg, A. C. (1981): The glycolysis and respiration of tumors. Acad. Press, 21: 314-317.

Al Sadoon, M. K. (1991): Metabolic rate-temperature curves of the horned viper, Cerastes cerastes gasperetti, the moila snake, Malpolon moilensis, and the adder, Vipera berus. Comparative Biochemistry and Physiology a Comparative Physiology, 99A: 119-122.

Al Sadoon, M. K.; Al Farraj, S. A. and Abdo, N. M. (1991): Survey of the reptilian fauna of the Kingdom of Saudi Arabia. 3. An ecological survey of the lizard, amphisbaenian and snake fauna of Al-Zulfi area. Bulletin of the Maryland Herpetological Society, 27: 1-22.

Al-Jammaz, I. (1995): Effects of the venom of Walterinnesia aegyptia and Echis coloratus on solute levels in the plasma of albino rats. J. King. Saud Univ.7, Science, (1): 63-69.

Al-Jammaz, I.; Al-Ayed, M. I. and Al-Yahya, H. (1998): Effect of acute envenomation with LD50 of B. arietans . Ain. Shams. Sci. Bull.,36: 207-222.

Al-Jammaz, I.; Al-Sadoon, M. K. and Fahim, A. (1999): Effect of LD50 dose of Echis coloratus venom on serum and tissue metabolites and some enzyme of male albino rats. J. King Saud Univ., 11, Science, (2): 61-68.

Burdmann, E. A.; Woronik,V.; Euthymia. B. A.; Regina, P. C.; Saldanha, A, L B.; Barreto, O. C. O and Marcondes, M. (1993): Snakebite-Induced Acute Renal Failure: an Experimental Model Am. J. Trop. Med. Hyg., 48(1): 82-88.

Cherlin, V. A. (1990): Taxonomic revision of the snake genus Echis (Viperidae). 2. An analysis of taxonomy and description of new forms. Trudy Zoologicheskogo Instituta 207: 193-223.

Doumas, B. T.; Watson, W. A. Biggs, H. G. (1971): Determination of serum albumin. Standard methods. Clin. Chem., 7: 87-96.

Doumas, B. T.; Biggs, H. G.; Arends, R. L. and Pinto, P. C. V. (1972): Determination of serum albumin. Standard methods. Clin. Chem, 7: $175-188$.

EL-Asmar, M. F.; Farag, R. M.; Shoukry, S. and EL-Shimi, I. R. (1979): Effect of scorpion Leivrus quinquestriatus $\mathrm{H} \& \mathrm{E}$ venom on lipid metabolism Toxicon 17: 279 - 283.

Fahim, A. (1998): Biological effects of the viper B. arietans, crude venom on albino rats. Egypt. J. Zool., 30: 35-54.

Fox, J. W. and Serrano, S. M. (2008): Exploring snake venom proteomes: multifaceted analyses for complex toxin mixtures. Proteomics, 8(4): 909-920.

Gasperetti, J. (1988): Snakes of Arabia. Fauna of Saudi Arabia, 9: 169-50.

Guyton, A. C. and Hall, J. E. (2000): The microcirculation and the lymphocytic system: capillary fluid exchange, interstitial fluid and lymph flow. In: Medical physiology $10^{\text {th }}$ ed. (Guyton, A. C. and Hall, J. E., eds), chapter No. 16, pp 162 - 174. W. B.

Hare, R. S. (1950): Endogenous creatinine in serum and urine. Pro. Soc. Exp. Biol. Med., 147-148

Hassan, F.; El-Hawary, M. F.; Gazawi, A.; Anis, A. Wanas, S. (1980): Biochemical properties of Egyptian Cerastes venoms in relation to geographic distribution. Zeitschrift fur Ernahrungs wissenschaft, 19:259-265.

Hibi, T. and Dosh, H. M. (1986): Limiting dilution analysis of the B cell compartement in human bone marrow. Eur. Immunol., 16: 139 - 145. Lewis, R. L. and Gutmann, L. (2004): Snake venoms and the neuromuscular junction. Semin eurol., 24(2):175-179. 
Lewis, R. L. and Gutmann, L. (2004): Snake venoms and the neuromuscular junction. Semin Neurol., 24(2):175-179. Liu, Y. J.; Johnson, G. D.; Gordon, J. and Maclennan, I. C. M. (1992): Germinal centers in T-cell-dependent antibody responses. Immunol. Today, 13: 17 - 21.

MacMillan, R.; Longmire, R. L.; Levere, R. D. and Abraham, N. G. (1994): Immunoglobin synthesis by human lymphoid tissues: normal bone marrow as a major site of IgG production. J. Immunol. , 109: 1386-1394.

Maria, D. A.; Vassa o, R. C. and Ruiz, I .R .G. (2003): Haematopoietic effects induced in mice by the snake venom toxin jararhagin. Toxicon, 42: 579-585.

Marinova, T. S.; Georgieva, T. R. and Pantev, T. (1991): Proteins synthesis changes in peripheral blood leukocytes following in vivo and in vitro irradiation mammalian spermatogonia. Rentgen. Radiolog., 30 (1): 63 - 66.

Marsh, N. A.; Fyffe, T. L. and Bennett, E. A. (1997): Isolation and partial characterization of a prothrombin-activating enzyme from the venom of the Australian rough-scaled snake (Tropidechis carinatus).Toxicon,35(4):563-571.

Marsh, N.; Gattullo, D.; Pagliaro, P. and Losano, G. (1997): The Gaboon viper, and Bitis gabonica: hemorrhagic, metabolic, cardiovascular and clinical effects of the venom .Lif. Sci., 61(8): 763-769.

Maxine, M. and Benjamin, B. S. (1985): Outline of veterinary clinical pathology. $3^{\text {rd }}$ edition, Colorado state university, printed in India at Rakha printers PVT. LDT. New Delhi.

Meier, J. and Stocker, K. (1991): Effect of snake venoms on homeostasis. Toxicology 21 (3): 1711-1820.

Meier, J. and Theakston, R. D. Q. (1986): Approximate LD $_{50}$ Determinations of snake venoms using eight to ten experimental animals. Toxicon, 24(4): 395-401.

Mohamed, A. H.; El-Serougi, M. S. and Kamel, A. M. (1964): Effect of Walterinnesia aegyptia venom on blood sodium, potassium and catecholamines and urine 17ketosteroids Toxicon, 2: 103-107.

Mohamed, A. H.; Foaud, S.; Abbas, F.; Abd-El-Aal, A.; Abd-El-Baset, A.; Abbas, N. and Zahran, F. (1980): Metabolic studies of the Egyptian and allied African snake venoms. Toxicon, 18: $381-383$.

Moav, B.; Moroz, Ch. and de Vries, A. (1963): Activation of fibrinolytic system of the guinea pig following inoculation of Echis colorata venom. Toxicon, 1: 109-112.

Ohhira, M.; Gasa, S.; Makita, A.; Sekiya, C.; and Namiki, M. (1991): Elevated carbohydrate phosphotransferase activity in human hepatoma and phosphorylation of cathepsin D. Br. J. Cancer, 63: 905 -908.

Omran, M. A.; Abdel-Nabi, I. M. and El-Naggar, M. H. (1997): Serum biochemical and hormonal parameters as biomarkers for the toxic effects of Egyptian cobra (Naja haje) envenmation. J. Nat. Toxins, 6: 69-83.

Patton, C. J. and Crouch, S. R. (1977): Spectrophotometeric and kinetics investigation of the Berthelot reaction for determination of ammonia, Anal. Chem. 49: pp. 464-69.

Peters, T. Jr. (1968): Proposals for standardization of total protein assays. Clin. Chem., 14 (12): 1147- 1159.

Pung, Y. F.; Wong, P. T.; Kumar, P. P.; Hodgson, W. C. and Kini, R. M. (2005): Ohanin, a novel protein from king cobra venom, induces hypolocomotion and hyperalgesia in mice. J. Biol. Chem., 280: 13137 -13147. 
Rahmy, T. R.; Ramadan, R. A.; Farid, T. M. and EL-Asmar, M. F. (1995): Renal lesions induced by cobra envenomation .J. Egypt. Ger. Soc. Zool., 17(C): 251271.

Rahmy, T. R. and Hemmaid, K. Z. (2000): Histological and histochemical alterations in the liver following intramuscular injection with sublethal dose of the Egyptian cobra venom. J. Nat. Toxins, 9: 21-32

Richmond, W. (1973): Preparation of properties of the cholesterol oxidase from nacordia sp. And its application of the enzymatic assay of total cholesterol in serum. Clin. Chem., 19: 1350- 1356.

Roldan, E.; Garcia-Pardo, A. and Brieva, J. A. (1992a): VLA-4-fibronectin interaction is required for the terminal differentiation of human bone marrow capable of spontaneous and high rate immunoglobulin secretion. J. Exp. Med., 175: 1739 $-1747$.

Roldan, E.; Rodriguez, C.; Navas, G.; Parra, C. and Brieva, J. A. (1992b): Cytokine network regulating terminal maturation of human bone marrow $\mathrm{B}$ cells capable of spontaneous and high rate Ig secretion in vitro. J. Immunol., 149: 2367- 2371.

Salazar, A. M.; Rodriguez-Acosta, A., Girón, M. E.; Aguilar, I. and Guerrero, B. (2007): Comparative analysis of the clotting and fibrinolytic activities of the snake venom (Bothrops atrox) from different geographical areas in Venezuela. Hromb.Res., (1): 5-104.

Sant, S. M. and Purandare, N. M. (1972): "Autopsy Study of Cases of Snake Bite with Special Reference to Renal Lesions”. J. Postgrad. Med., 18: 181-188.

Sasa, M. (1999): Diet and snake venom evolution: can local selection alone explain intraspecific venom variation?. Toxicon, 37(2): 249-252.

Schneemann, M.; Cathomas, R.; Laidlaw, S. T.; El Nahas, A. M; Theakston, R. D.; Warrell, D A. (2004): Life-threatening envenoming by the Saharan horned viper (Cerastes cerastes) causing micro-angiopathic haemolysis, coagulopathy and acute renal failure: clinical cases and review, 97(11): 717-727.

Sleat, D. E.; Wang, Y.; Sohar, I.; Lackland, H., Li, Y.; Li, H.; Zheng, H. and Lobel, P. (2006): Identification and validation of mannose 6-phosphate glycoproteins in human plasma reveals a wide range of lysosomal and non-lysosomal proteins. Mol. Cell. Proteomics, 5: $1942-1956$.

Soslau, G.; El-Asmar, M. F. and Parker, J. (1988): Cerastes cerastes (Egyptian sand viper) venom induced platelet aggregation as compared to other agonist. Biochem. Biophys. Res. Commun., 150 (3): pp. 909 - 916.

Tan, N. H. and Ponnudurai, G. (1990): A comparative study of the biological properties of venoms from snakes of the genus vipera (True adders). Comp. Biochem. Physiol., 96 (B): 683- 688.

Theakston, R. D. G. (1983): The application of immunoassay techniques including enzyme-linked immunoassay (ELISA) to snake venom research. Toxicon, 21: 341-352.

Tilbury, R. C.; Madkour, M. M.; Saltissi, D. and Suleiman, M. (1987): Acute renal failure following the bite of Burton`s Carpet Viper Echis coloratus Gunther in Saudi Arabia: Case report review. Saudi. Med. J., 8: 87-95.

Trinder, P. (1969): Enzymatic determination of glucose. Ann. Clin. Biochem., 6- 24.

Warrell, D. A. (1993): Venomous bites and stings in Saudi Arabia. Saudi Medical Journal, 14: 196-202.

Warrell, D. A. (1995): Clinical toxicology of snake bites in Africa and MiddleEast/ Arabian Peninsula. In: Meier, J., White, J. (Eds.), Handbook of Clinical 
Toxicology of Animal Venoms and poisons, Boca.Raton, Florida, CRC Press, pp: 433-492

Warrell, D. A. (1997): Geographical and intraspecies variation in the clinical manifestations of envenoming by snakes. Symp. Zool. Soc. London, 70:189203.

Warrell, D. A and Arnett, C (1976): The importance of bites by the saw-scaled or carpet viper (Echis carinatus). Epidemiological studies in Nigeria and review of the world literature. Acta Tropica(Basel), 33: 307-341.

Werner, Y. L. (1994): Head size variation in Cerastes (Ophidia: Viperidae) parallels body size variation in potential prey (Rodentia: Gerbillinae). Snake 26: 57-60.

Werner, Y. L., Le Verdier, A., Rosenman, D. and Sivan, N. (1991): Systematics and zoogeography of Cerastes (Ophidia: Viperidae) in the Levant: I.Distinguishing Arabian from African Cerastes cerastes. Snake 23: 90-100.

West, J. B. (1985): Blood and the plasma proteins: Function and composition of blood. In: Best and Taylor's physiological basis of medical practice. 11th edt. Williams and Wilkins, Baltimore, pp. 334 - 340.

Yamazaki, Y. and Morita, T. (2007): Snake venom components affecting blood coagulation and the vascular system: structural similarities and marked diversity. Curr. Pharm Des., 13(28): 2872-2886.

Young, D. S. (1975): Clin. Chem. 5-20.

Zingali, R. B.; Jandrot-Perrus, M.; Guillin, M. C. and Bon, C. (1993): Bothrojaracin, a new thrombin inhibitor isolated from Bothrops jararaca venom: characterization and mechanism of thrombin inhibition. Biochemistry, 32(40):10794-10802.

\section{ARABIC SUMMARY}



